Note

\title{
The Mode of Action of Sodium Hypochlorite in the Decolorization of Azo Dye Orange II in Aqueous Solution
}

\author{
HIROMI URANO, AND SATOSHI FUKUZAKI* \\ Industrial Technology Center of Okayama Prefecture, \\ 5301 Haga, Kita-ku, Okayama 701-1296, Japan
}

Received 16 September, 2010/Accepted 21 May, 2011

\begin{abstract}
The effect of sodium hypochlorite $(\mathrm{NaOCl})$ on the decolorization of azo dye orange II (4[(2-hydroxy-1-naphthalenyl) azo]-benzenesulfonic acid, monosodium salt) in aqueous solution was studied as a function of $\mathrm{pH}$. The first-order rate constant of color reduction $(k)$ was evaluated from the curve of color reduction in the initial stage of decolorization. The $k$ values increased with increasing the $\mathrm{pH}$ from 5.4 to 9.3 and the $\mathrm{NaOCl}$ concentration from $2.82 \times 10^{-4}$ $\mathrm{M}$ to $1.13 \times 10^{-3} \mathrm{M}$. It was found that $k$ depended on the concentration of $\mathrm{OCl}^{-}$, but not on $\mathrm{HOCl}$. On the other hand, $k$ decreased markedly at $\mathrm{pHs}$ more than 10 , depending on $\mathrm{pH}$. This suggested that the reactivity of the orange II molecule with $\mathrm{OCl}^{-}$decreased probably due to the competitive action of the hydroxide ion under alkaline conditions. It could be concluded that controlling the solution $\mathrm{pH}$ and the $\mathrm{OCl}^{-}$concentration was indeed a key factor determining the rate of decolorization of orange II in aqueous solution.
\end{abstract}

Key words : Decolorization of azo dye/Orange II/Sodium hypochlorite/Dissociated hypochlorite ion/ Hydroxide ion.

Sodium hypochlorite $(\mathrm{NaOCl})$ has been widely used in disinfection, cleaning, decolorizing (or bleaching), and deodorizing operations in the food industry. In a diluted $\mathrm{NaOCl}$ solution, over the $\mathrm{pH}$ range of 5 to 10 , there is an equilibrium between two free available chlorine (FAC) forms, i.e., undissociated hypochlorous acid $(\mathrm{HOCl})$ and the dissociated hypochlorite ion $\left(\mathrm{OCl}^{-}\right)$. It is generally recognized that $\mathrm{HOCl}$ is the active species in the antimicrobial action (Fair et al., 1948; Brazis et al., 1958), whereas the concentration of $\mathrm{OCl}^{-}$is a key factor determining the cleaning efficiency (Urano and Fukuzaki, 2005; Fukuzaki et al., 2007). These findings imply that the efficacy of $\mathrm{NaOCl}$ depends on the ratio of concentrations of $\mathrm{HOCl}$ and $\mathrm{OCl}^{-}$, i.e., the $\mathrm{pH}$ of $\mathrm{NaOCl}$ solution. On the other hand, in the decolorization or bleaching of pigmented equipment, towels, clothing, and wastewater, $\mathrm{NaOCl}$ has been used without controlling the $\mathrm{pH}$ of the $\mathrm{NaOCl}$ solution although the ap-

* Corresponding author. Tel: +81-86-286-9600, Fax: +8186-286-9631, E-mail: satoshi_fukuzaki (a)pref.okayama.lg.jp plication of $\mathrm{NaOCl}$ began approximately 100 years ago. As to the decolorization property of $\mathrm{NaOCl}$, the mechanism (Gregory and Stead, 1978; Kanazawa and Onami, 2001) and kinetics (Bredereck and Schumacher, 1993; Kanazawa and Onami, 1995; Sudoh and lijima, 1989) of the degradation of azo dyes by $\mathrm{NaOCl}$ in aqueous solution have been investigated with the design for chlorine-fast dyes and wastewater treatment in mind. However, the effect of $\mathrm{pH}$ on the decolorization of azo dyes by $\mathrm{NaOCl}$ in aqueous solution is not fully understood. Azo dyes account for up to $70 \%$ of all textile dyestuffs produced (Zollinger, 1987). It is important to know the ability of $\mathrm{HOCl}$ and $\mathrm{OCl}^{-}$to decolorize azo dyes in order to understand the decolorization properties of $\mathrm{NaOCl}$.

The objective of this study was to investigate the mode of action of $\mathrm{NaOCl}$ in the decolorization of azo dye solution. We used orange II (4-[(2-Hydroxy-1naphthalenyl)azo]-benzenesulfonic acid, monosodium salt) as a model pigment. Orange II contains a hydroxyl group conjugated with the azo-linkage (-N 
$=\mathrm{N}$ - or $-\mathrm{NH}-\mathrm{N}=$ ), and it exists as an equilibrium mixture of two tautomeric forms, azo (Fig. 1A) and hydrazone (Fig. 1B), in aqueous solution (Gordon and Gregory; 1983; Koukouraki and Diamadopoulos; 2003). Orange II is also a weak acid with a dissociation constant of $\mathrm{p} K_{\mathrm{a}}=11.4$ (Oakes and Gratton, 1998). Thus, dissociation occurs in the alkaline $\mathrm{pH}$ region to form a common dissociated form (Fig. 1C). In this study, the effect of $\mathrm{NaOCl}$ on the decolorization of the orange II solution was studied as a function of $\mathrm{pH}$.

Orange II was obtained from Wako Pure Chemical Industries, Ltd. (Osaka) and used as received. The concentration of orange II solution was determined by measuring its absorbance at $484 \mathrm{~nm}$ (Abs.484nm) that gives an absorption maximum with a molar extinction coefficient of $1.896 \times 10^{4} \mathrm{M}^{-1} \cdot \mathrm{cm}^{-1}$. Sodium hypochlorite $(\mathrm{NaOCl})$ was of extra pure grade and purchased from Kanto Chemical, Co., Inc. (Tokyo) in the form of a $6 \%$ FAC solution. The concentration of $\mathrm{NaOCl}$ was determined as FAC by the N,N-diethylphenylene-diamine (DPD) method. The concentration of $\mathrm{OCl}^{-}$in $\mathrm{NaOCl}$ solution was calculated using an acid dissociation constant $\left(\mathrm{p} K_{a}\right)$ of 7.53 (Morris, 1966). Potassium di-hydrogen phosphate $\left(\mathrm{KH}_{2} \mathrm{PO}_{4}\right)$ and di-potassium hydrogen phosphate $\left(\mathrm{K}_{2} \mathrm{HPO}_{4}\right)$ were special grade reagents and purchased from Nacalai Tesque, Inc. (Kyoto). Stock solutions of orange II, NaOCl, and phosphate buffer were prepared by dilution with deionized water. All other chemicals were special grade reagents and purchased from commercial sources.

Batchwise decolorization experiments were conducted at $25^{\circ} \mathrm{C}$ in a $3-\mathrm{ml}$ quartz cell (optical path length of $1 \mathrm{~cm}$ ), which was installed in a cell folder, equipped with a temperature controller and magnetic

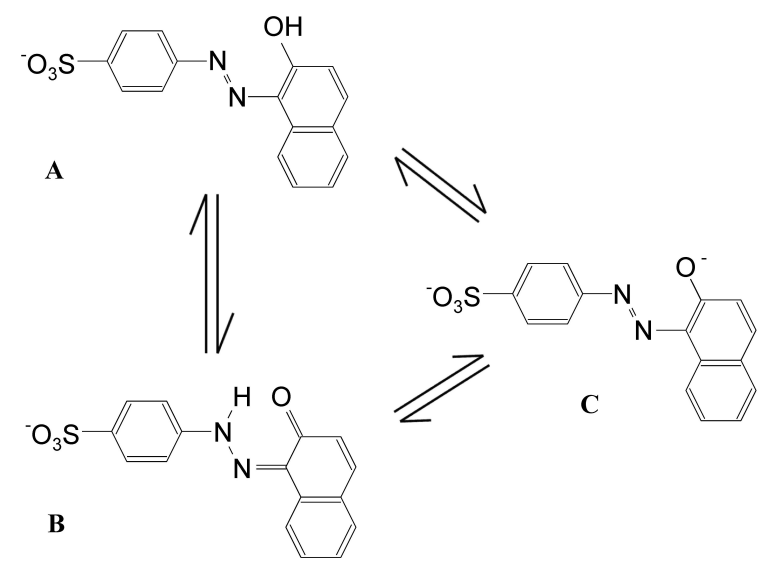

FIG. 1. Structures of orange $\|$ in aqueous solution. (A) Azo; (B) hydrazone; (C) common ion. stirrer, of a spectrophotometer (UV-3100PC; Shimadzu, Kyoto). Before the experiment, the quartz cell and cell folder were kept at $25^{\circ} \mathrm{C}$, and then 0.75 $\mathrm{ml}$ of $\mathrm{NaOCl}$ solution and $0.75 \mathrm{ml}$ of $0.4 \mathrm{M}$ phosphate buffer solution, pHs of which were adjusted from 5.4 to 11.7 , were poured into the cell and stirred for 10 min, as the pre-heating treatment. After this was allowed to stand for $10 \mathrm{~min}$, to initiate the decolorizing reaction, $1.5 \mathrm{ml}$ of orange $\mathrm{II}$ solution pre-heated at $25^{\circ} \mathrm{C}$ was added into the cell, and spectroscopic measurement of $A b s .484 \mathrm{~nm}$ of the mixed solution was immediately started. The decrease in $A b s_{.484 n m}$ was monitored at intervals of 5,15 , and $30 \mathrm{~s}$ depending on the degree of color reduction. There was no $\mathrm{pH}$ change throughout the decolorization reaction in all experiments.

To analyze the decolorization of orange $\|$, the concept that a first-order reaction occurs during decolorization process was used. The curve of decolorization was obtained by plotting the natural logarithm of the concentration of orange $\|$ against the reaction time. The rate constant of the color reduction, $k$, was estimated by evaluating the slope of the best-fit straight line, using the linear regression method (correlation coefficient $\geqq 0.99$ ), for the first portion of the decrease of orange $\mid \mathrm{I}$ in the initial stage of decolorization.

In [Orange ||$]=$ In [Orange $\left.\|_{0}\right]-k t \quad(1)$ where [Orange $\mathrm{I}_{0}$ ] and [Orange $\mathrm{II}$ ] are the concentrations of orange $\mathrm{II}$ at zero time and any given time, $t$, respectively.

To examine the effect of $\mathrm{pH}$ on the decolorization, experiments were conducted at an initial orange II concentration of $8.70 \times 10^{-5} \mathrm{M}\left(\right.$ Abs $\left._{.484 \mathrm{~nm}}=1.65\right)$ over the $\mathrm{pH}$ range from 5.4 to 11.7 , using $2.82 \times 10^{-4}, 5.64$ $\times 10^{-4}$, and $1.13 \times 10^{-3} \mathrm{M} \mathrm{NaOCl}$. Figure 2 shows typical curves of decrease in orange II during decolorization by $\mathrm{NaOCl}$ at different $\mathrm{pHs}$. The straight lines (solid lines) reflect the initial rate of color reduction. It was found that the rate of color reduction was markedly affected by both $\mathrm{pH}$ and the $\mathrm{NaOCl}$ concentration. At $2.82 \times 10^{-4} \mathrm{M} \mathrm{NaOCl}$, the rate of color reduction was slower at the weak acidic and neutral $\mathrm{pH}$ regions ( $\mathrm{pH} 6$ to 7 ) and it increased gradually with increasing pHs up to 9.3 (Fig. 2A). These features were more pronounced when using $\mathrm{NaOCl}$ concentrations of $5.64 \times 10^{-4}$ to $1.13 \times 10^{-3} \mathrm{M}$ (Figs. $2 \mathrm{~B}$ and $2 \mathrm{C}$ ). More rapid decolorization was achieved at $\mathrm{pH}$ 9.3 at all $\mathrm{NaOCl}$ concentrations. On the contrary, it was found that the decreases in the rate of color reduction were observed at $\mathrm{pHs}$ more than 10.

Figure $3 \mathrm{~A}$ shows the $k$ values obtained from the graphs in Fig. 2, as a function of $\mathrm{pH}$. Over the $\mathrm{pH}$ range from 5.4 to $9.3, k$ increased markedly with 


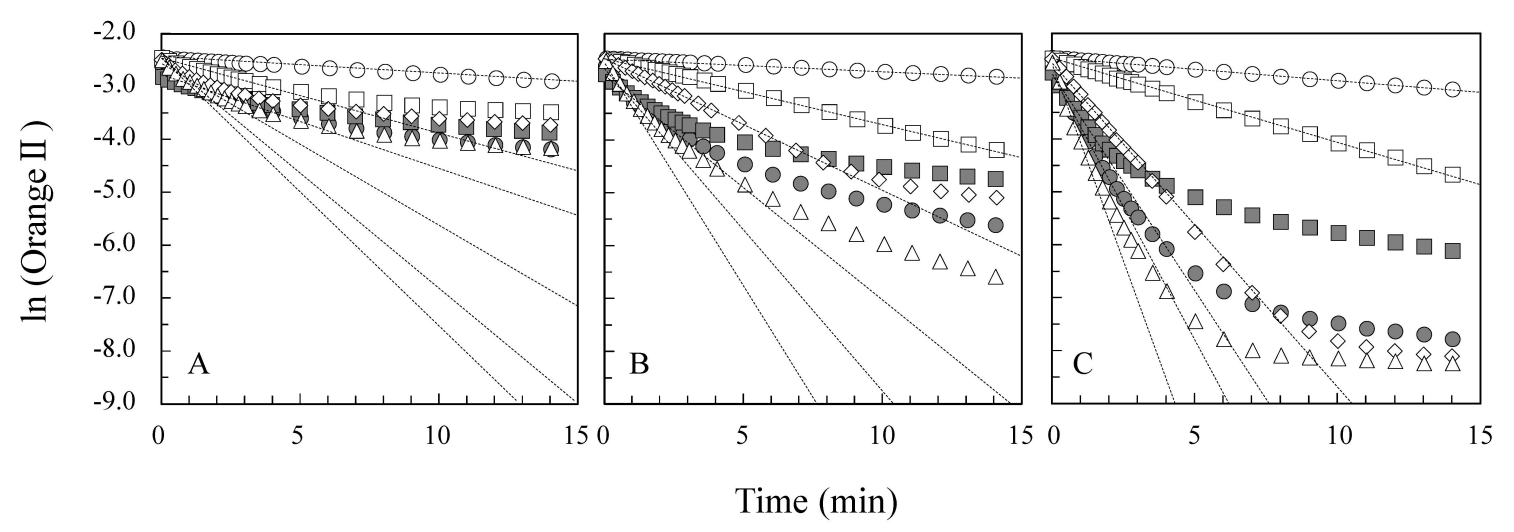

FIG. 2. Curves characterizing decrease in orange $\|$ during the decolorization with $\mathrm{NaOCl}$ at $2.82 \times 10^{-4}(\mathrm{~A})$, $5.64 \times 10^{-4}(\mathrm{~B})$ and $1.13 \times 10^{-3} \mathrm{M}(\mathrm{C})$. The initial orange $\|$ concentration was $8.70 \times 10^{-5} \mathrm{M}(\mathrm{Abs} .484 \mathrm{~nm}=$ 1.65). The solid lines denote the slopes given by linear curve fitting for the portion of rapid decrease of orange II in the initial stage of decolorization. Symbols $(\mathrm{pH}):(\mathrm{A}) \bigcirc 6.0, \square 7.0, \diamond 8.1, \triangle 9.3, \bigcirc 10.4, \square 10.9$; (B) $\bigcirc$ 5.4, $\square$ 6.3, $\diamond$ 6.8, $\triangle$ 9.3, 10.4, $\square$ 10.9; (C) $\bigcirc$ 5.4, $\square$ 6.2, $\diamond 7.1, \triangle 9.3, \bigcirc 10.4, \square 10.9$.
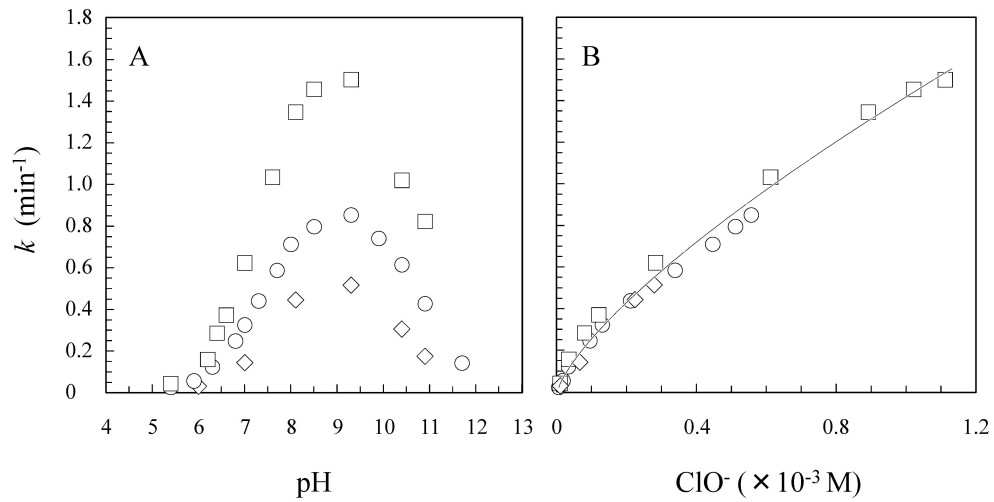

FIG. 3. Effect of $\mathrm{pH}$ and the $\mathrm{NaOCl}$ concentration on the $k$ value for the decolorization of orange $\|$ by $\mathrm{NaOCl}$. (A) Plotted as a function of $\mathrm{pH}$; (B) plotted as a function of the initial concentration of dissociated $\mathrm{OCl}^{-}$at $\mathrm{pHs}$ below 10 . Experimental conditions are given in the legend to Figure 2. The solid line was derived by curve-fitting using the linear regression method. Symbols (initial $\mathrm{NaOCl}$ concentration; M): $\diamond 2.82 \times 10^{-4}, \bigcirc 5.64 \times 10^{-4}, \square 1.13 \times 10^{-3}$.

increasing the solution $\mathrm{pHs}$ and it reached an maximum value at $\mathrm{pH}$ 9.3. Under weak acidic conditions ( $\mathrm{pH} 5.5$ to 6.5), where undissociated $\mathrm{HOCl}$ is prevalent, $\mathrm{NaOCl}$ exerted little action in the decolorization of orange 11 in spite of its high concentration (2.82 $\times 10^{-4}$ to $1.13 \times 10^{-3} \mathrm{M}$ ) . It seemed that $k$ increased with the increase in the $\mathrm{OCl}^{-}$concentration over the $\mathrm{pH}$ range from 5.4 to 9.3. To clarify the action of $\mathrm{OCl}^{-}$, we put aside the data obtained at pHs more than 10 and plotted the $k$ values against the initial $\mathrm{OCl}^{-}$concentrations (Fig. 3B). It was clearly noted that the $k$ values increased in an $\mathrm{OCl}^{-}$-dependent manner. The graph of the $\mathrm{OCl}^{-}$concentration versus the $k$ value gave the following relationship (correlation coefficient $=0.985$ ):

$$
k=231 \times\left[\mathrm{OCl}^{-}\right]^{0.736}
$$

These data demonstrated that $\mathrm{OCl}^{-}$, as a dissociated form of FAC, was the active species in the decolorization of orange II in aqueous solution. It has been reported that the rate-determining step in the oxidative degradation of azo dyes was the cleavage of azolinkage moiety (Kanazawa and Onami, 2001). The Cl atom in $\mathrm{OCl}^{-}$behaves as $\mathrm{Cl}^{+}$, a strong electrophile, and combined with a pair of electrons in parts of the substrate that have high electron densities (Fukuzaki, 2006). The azo-linkage on orange II has a high electron density and hence it is readily chlorinated by $\mathrm{OCl}^{-}$having the high polarity. The electrophilic action of $\mathrm{OCl}^{-}$toward nucleophilic $\mathrm{N}$ atoms on orange II molecules is responsible for the decolorization of the orange II solution. On the other hand, undissociated $\mathrm{HOCl}$ is electrically neutral and has a lower polarity 
than $\mathrm{OCl}^{-}$. These might result in the lower reactivity of orange || with $\mathrm{HOCl}$. This phenomenon is similar to that of the low reactivity of ammonia and $\mathrm{N}$-organo compounds with $\mathrm{HOCl}$ (Koukouraki and Diamadopoulos, 2003; Takehara and Fukuzaki, 2006).

In this study, the maximum $k$ values were found to occur at $\mathrm{pH} 9.3$ at different $\mathrm{NaOCl}$ concentrations, whereas they decreased markedly at pHs more than 10 (Fig. 2). It is thought that no structural change occurs in the azo-linkage moiety, a target of $\mathrm{Cl}^{+}$attack, on orange II even though orange II dissociates to a common anion under alkaline conditions (Fig. 1C). These findings suggest that the decrease in the $k$ value at higher $\mathrm{pHs}$ was due to the interfering action of coexisting $\mathrm{OH}^{-}$. At pHs lower than 9.3, the concentrations of $\mathrm{OH}^{-}$were lower by at least one to two orders of magnitude than those of $\mathrm{OCl}^{-}\left(2.82 \times 10^{-4}\right.$ to $\left.1.13 \times 10^{-3} \mathrm{M}\right)$. Under these conditions, $k$ was proportional to $\left[\mathrm{OCl}^{-}\right]^{0.736}$ (eq. 2). The low value of the exponent of 0.736 implies the existence of ratedetermining factors. It is likely that low concentrations of $\mathrm{OH}^{-}$might somewhat inhibit the action of $\mathrm{OCl}^{-}$ even at pHs below 9.3. On the other hand, at pHs above 10, the concentrations of $\mathrm{OH}^{-}$become the same order of magnitude as those of $\mathrm{OCl}^{-}$. Both $\mathrm{OH}^{-}$and $\mathrm{OCl}^{-}$show electrostatically similar behavior in aqueous solution. The accessibility of $\mathrm{OCl}^{-}$to reactive sites such as the azo-linkage on orange II would go down by concentrated $\mathrm{OH}^{-}$. It is reasonable that the attack of $\mathrm{OCl}^{-}$on orange II is competitively inhibited by $\mathrm{OH}^{-}$at the alkaline $\mathrm{pH}$ region $(\mathrm{pH}>10)$.

The results presented here provide useful information concerning the decolorization of azo dyes by $\mathrm{NaOCl}$. The concentration of $\mathrm{OCl}^{-}$, but not of $\mathrm{HOCl}$, is indeed the key factor determining the efficacy of $\mathrm{NaOCl}$ in the decolorization of orange II. The rate constant of decolorization increased with increasing pHs up to 9.3. However, an excess $\mathrm{OH}^{-}$behaves as a competitive inhibitor for $\mathrm{OCl}^{-}$, thereby interfering with the decolorization by $\mathrm{OCl}^{-}$. For optimizing the decolorization process by $\mathrm{NaOCl}$, therefore, it is very important to control the $\mathrm{pH}$ of the $\mathrm{NaOCl}$ solution or pigmented solution by considering both the $\mathrm{OCl}^{-}$and $\mathrm{OH}^{-}$concentrations.

\section{REFERENCES}

Brazis, A. R., Leslie, J. E.. Kabler, P. W., and Woodward, R. L. (1958) The inactivation of spores of Bacillus globigii and Bacillus anthracis by free available chlorine. Appl. Microbiol., 6, 338-342.

Bredereck, K., and Schumacher, C. (1993) Structure reactivity correlations of azo reactive dyes based on $\mathrm{H}$-acid. I. NMR chemical shift values, pKa values, dyestuff aggregation and dyeing behavior. Dyes and Pigments, 21, 2343.

Bredereck, K., and Schumacher, C. (1993) Structure reactivity correlations of azo reactive dyes based on $\mathrm{H}$-acid. II. Dye degradation by hypochlorite. Dyes and Pigments, 21, 45-66.

Fair, G. M., Morris, J. C., Chan, S. L., Weil, I., and Burden, R. P. (1948) The behavior of chlorine as a water disinfectant. J. Am. Water Assoc., 40, 1051-1061.

Fukuzaki, S. (2006) Mechanisms of actions of sodium hypochlorite in cleaning and disinfection processes. Biocontol Sci., 11, 147-157.

Fukuzaki, S., Urano, H., and Yamada, S. (2007) Effect of $\mathrm{pH}$ on the efficacy of sodium hypochlorite solution as cleaning and bactericidal agents. J. Surface Finish Soc. Jpn., 58, 465-469.

Gordon, P. F., and Gregory, P. (1983) Organic Chemistry in Color, Springer- Verlag, New York.

Gregory, P., and Stead, C. V. (1978) The degradation of water-soluble azo compounds by dilute sodium hypochlorite solution. J. Soc. Dyers Colour, 94, 402 -407.

Kanazawa, H., and Onami, T. (1995) Degradation of Azo dyes by sodium hypochlorite 3 . estimation of the rate equation for degradation of orange $G$ and benzopurpurine. Bull. Chem. Soc. Jpn., 68, 2483-2489.

Kanazawa, H., and Onami, T. (2001) Mechanism of the degradation of orange $\mathrm{G}$ by sodium hypochlorite. Color. Technol., 117, 323-327.

Koukouraki, E., and Diamadopoulos, E. (2003) Modelling the formation of THM (trihalomethanes) during chlorination of treated municipal wastewater. Water Sci. Technol., 3, 277-284.

Morris, J. C. (1966) The acid ionization constant of $\mathrm{HOCl}$ from 5 to $35^{\circ}$. J. Phys. Chem., 70, 3798-3805.

Oakes, J., and Gratton, P. (1998) Kinetic investigations of azo dye oxidation in aqueous media. J. Chem. Soc. Perkin Trans. 2, 1857-1864.

Sudoh, Y., and lijima, T. (1989) Oxidative fading reaction of azo dye in aqueous solution with sodium hypochlorite. Sen-i Gakkaishi, 45, 332-334.

Takehara, A., and Fukuzaki, S. (2006) Relationship between the $\mathrm{pH}$ and decrease in available chlorine of sodium hypochlorite in the presence of organic compounds or during freezing treatment. Report of Ind. Technol. Ctr. Okayama, 32, 10-13 (in Japanese).

Urano, H., and Fukuzaki, S. (2005) The mode of action of sodium hypochlorite in the cleaning process. Biocontrol Sci., 10, 21-29.

Zollinger, H. (1987) Colour Chemistry: Syntheses, Properties and. Applications of Organic Dyes and Pigments. VCH Publishers, Inc., New York. 